\title{
PHARMACOLOGICAL S'TUDIES WITH SOME NEWLY SYNTHESIZED PHENOTHIAZINES EXHIBITING LESSER EXTRAPYRAMIDAL REACTIONS
}

\author{
V.N. SHARMA, R.L. MITAL,* S.P. BANERJEE AND H.L. SHARMA \\ Deparlment of Pharmacology, S.M.S. Medical College Jaipur and \\ *Department of Chemistry, University of Rajasthan, Jaipur, India \\ Receivel for publication October 5, 1968
}

The signs and symptoms due to extrapyramidal tract involvement are amongst the most common side effects in tranquillizer therapy, which is uniformly present in all the six group of drugs used in medicine (1). With many of these drugs, severe extrapyramidal symptoms are uncommon, but with those phenothiazines which contain a piperazine moiety in their side chain such untoward effects are the rulc rather than exception; e.g. trifuoperazine, prochlorperazine and perphenazine. Since these are the valuable drugs in psychiatry, control of their 6 xtrapyramidal side effects offers an important challenge.

Several intriguing views, regarding the relationship of tranquillizing activity and extrapyramidal reactions are reported in literature. Freyhan (2), Brune et al. (3) and Haase (4) are of the opinion that the ability of a drug to induce parkinson like syndrome bears a positive correlation with its therapeutic efficacy, and that the fine motor extrapyramidal reactions are "conditio sino qua non" for the essential efficacy of neuroleptic drugs. Conversely, Cole and Clyde (5), Brooks (6) and Hollister (1), believe that the suppression of parkinsonism does not lcad to the impairment of therapeutic efficacy of tranquillizers and that the clinical appearance of extrapyramidal syndrome in no way predicts the therapeutic response of a tranquillizer.

An endeavour to find out the inter-relationship of parkinsonism and antipsychotic activity of tranquillizers can profitably be made by taking the hypothesis of McGeer $e t$ al. (7) into consideration. According to these suggestions, there is an equilibrium within the brain between the two groups of biogenic amines: serotonin-catecholamine on one hand, while acetylcholine-histamine on the other. Parkinsonism is characterized by an imbalance between these two systems and can be corrected either by increasing the neurohumoral content of one system or by decreasing that of the other.

Since the therapeutic efficacy of phenothiazine group of tranquillizer bcars a close correlation with their antiserotonin (8) and antiadrenergic (9) activity, the two possible ways to inhibit parkinsonism, without interfering with antipsychosis, could be to enhance their antihistaminic or antiacetylcholine action. But potent antihistaminics amongst phenothiazine series e.g. promethazine, or ethopropazine possess little tranquillizing activity, while perphenazine and trifluoperazine which are weak antihistaminics are on 
the other hand potent tranquillizers. Therefore, the only way to reduce their parkinsonism liability is to increase their antiacetylcholine like action. Since oximes are well known as antidotes for organophosphorous poisoning (anti DFP), we speculated that anticholinergic quaternary oximes of phenothiazine drugs can provide a tranquillizer with lesser liability of extrapyramidal reaction and that the study with these compounds is likely to furnish certain clues for the inter-relationship of these two actions, one desirable and the other unwanted.

\section{MATERIALS}

Three well established phenothiazine tranquillizers, viz. chlorpromazine hydrochloride (CPZ), trifluoperazine dihydrochloride (TFP) and perphenazine dihydrochloride (PER) were selected for the present study. From the free bases of these drugs, phenocyloxime chlorpromazine bromide (I), diphenacyloxime trifluoperazine dibromide (II) and diphenacyloxime perphenazine dibromide (III) were synthesized by the procedure already reported (10). These compounds (I, II and III) were assessed for their parkinsonism liability and CNS depressant properties. The results were comparcd to their parent drugs viz. CPZ, TFP and PER respectively. The structural formulae of the compounds I, II and III are shown in Fig. 1.

(I)

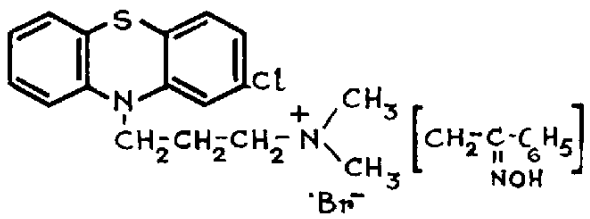

(II)

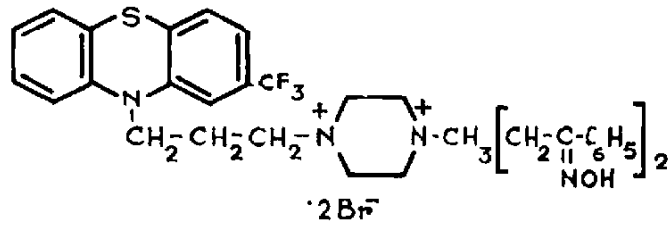

(III)

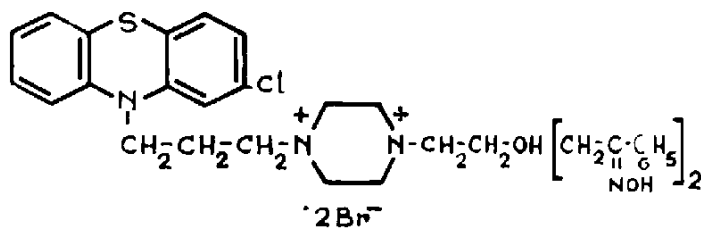

FIG. 1. Structural formulae of the compounds I, II and III, under study.

\section{METHODS}

\section{Solutions of the drugs}

The weighed quantity of each drug (I, II and III) was dissolved in a minimal but a known amount of warm ethanol and the volume was made up with warm distilled 
water so that the solution in no case contained more than $5 \%$ ethanol. It was than cooled to room temperature before use. Experiments were run simultaneously with solutions of the drugs as well as with the solvent alone $(5 \%$ aq. ethanol v/v). Since the control animals which received the solvent did not exhibit any pharmacological actions, the activities of the drugs will only be described here. The solutions of CPZ, TFP, PER, pentobarbitone sodium and $d$-amphetamine sulphate were made in distilled water.

II. Their CNS depressant property* was studied by employing the following battery of tests

1) Qualitative assessment of spontaneous molor activity (SMA) ptosis and influence of lactile and audilory stimuli on the mobility of mice by a double blind observational method (11)

These observations wcre made, upto 6 hours at hourly interval, after the intraperitoneal administration of different doses of drugs to a group of eight mice in each. The cffects were rated and compared to the group of ten control animals which received the solvent alone. 'The doses employed and the observations are recorded in Table 1.

TABLE 1, Effects of the phenothiazines on spontancous motor activity of the albino mice.

\begin{tabular}{|c|c|c|c|c|c|}
\hline Drug & $\begin{array}{l}\text { Dose } \\
\mathrm{mg} / \mathrm{kg}\end{array}$ & $\begin{array}{l}\text { No. of } \\
\text { animals }\end{array}$ & $\begin{array}{l}\text { Spontaneous } \\
\text { motor activity }\end{array}$ & $\begin{array}{l}\text { Response to the } \\
\text { auditory and } \\
\text { tactile stimuli }\end{array}$ & Ptosis \\
\hline CPZ & 3 & 8 & 册 & HHH & $H$ \\
\hline I & 3 & 8 & t & + & + \\
\hline I & 10 & 8 & H & + & $H$ \\
\hline TFP & 3 & 8 & $\mathrm{H}$ & HII & Hitf \\
\hline TFP & 1 & 8 & Ht & $+H$ & HH \\
\hline II & 3 & 8 & $H$ & Hit & H \\
\hline II & 1 & 8 & + & $\dot{+}$ & $+\dot{T}$ \\
\hline PER & 3 & 8 & H & HI & H \\
\hline PER & 1 & 8 & $H$ & H & itt \\
\hline III & 3 & 8 & H & $t ! t$ & H \\
\hline III & 1 & 8 & H & $H$ & $H$ \\
\hline Control & -- & 10 & $+t$ & $\dot{+}$ & + \\
\hline
\end{tabular}

+ Normal ; H insignificant ; HI significant ; HH marked effects

2) Potentiating effect of pentobarbitone sodium induced hypnosis

The procedure followed was that as described by Dandiya and Cullumbine (12). The experiments were conducted at room temperaturc $\left(25 \pm 1^{\circ} \mathrm{C}\right)$. Control animals received the solvent and pentobarbitone $(40 \mathrm{mg} / \mathrm{kg})$ only. The test animals were pretreated with different doses of phenothiazine derivatives before administering pentobarbitone sodium $(40 \mathrm{mg} / \mathrm{kg})$. The duration of sleep was calculated from the time taken by mouse when it had fallen asleep and when it regained the righting reflex. The doses of drugs, number of animals used and the results are enlisted in Table 2.

* The attitude that quatcrnary compounds do not cross blood brain barricr, was largely based on the lack of evidence to the contrary. During the past decade, reports have been made with incrcasing frequency and persistence that quaternaries do reach CNS to a sufficient degree to induce responses. Some quaternary phenothiazines have been reported to possess antitremorine activity which tempt to suspect the validity of the rule that quaternaries are devoid of direct CNS action because of their inability to pass blood brain barrier. Our findings also, seem to invalidate this widely accepted rule. For details in this regard refer Sharma et al. (10). 
TABLE 2. Effects of the phenothiazine drugs on pentobarbitone induced hypnosis.

\begin{tabular}{lccccc}
\hline Compound & $\begin{array}{c}\text { No. of } \\
\text { animals }\end{array}$ & $\begin{array}{c}\text { Dose } \\
\mathrm{mg} / \mathrm{kg}\end{array}$ & $\begin{array}{c}\text { Average slecping } \\
\text { time in min } \pm \text { S.E. }\end{array}$ & P value & $\begin{array}{c}\text { Percentage change } \\
\text { in sleeping time }\end{array}$ \\
\hline Control & 24 & - & $74.20 \pm 8.76$ & - & - \\
CPZ & 10 & 5 & $162.90 \pm 6.85$ & $<0.001$ & +119.54 \\
I & 10 & 5 & $100.10 \pm 20.90$ & - & +34.95 \\
TFP & 16 & 3 & $121.60 \pm 14.50$ & $<0.02$ & +63.88 \\
II & 16 & 3 & $120.77 \pm 10.94$ & $<0.01$ & +62.76 \\
PER & 10 & 1 & $91.70 \pm 8.35$ & - & +23.58 \\
III & 10 & 1 & $86.80 \pm 13.90$ & - & +16.98 \\
PER & 10 & 3 & $126.20 \pm 11.85$ & $<0.01$ & +70.08 \\
III & 10 & 3 & $117.00 \pm 10.11$ & $<0.02$ but & +57.68 \\
& & & & $>0.01$ & \\
\hline
\end{tabular}

TABLE 3. Effect of phenothiazine drugs on fighting behaviour of paired mice.

\begin{tabular}{lcccc}
\hline \multicolumn{1}{c}{ Drug } & $\begin{array}{c}\text { Dose } \\
\mathrm{mg} / \mathrm{kg}\end{array}$ & $\begin{array}{c}\text { No. of pairs } \\
\text { tried }\end{array}$ & $\begin{array}{c}\text { No. of pairs which } \\
\text { did not fight }\end{array}$ & $\begin{array}{c}\% \text { pair of mice in which } \\
\text { response was blocked }\end{array}$ \\
\hline Control & - & 12 & - & - \\
CPZ & 3 & 12 & 3 & 25 \\
CPZ & 5 & 12 & 7 & 58.33 \\
CPZ & 10 & 12 & 12 & 100 \\
I & 5 & 12 & 1 & 8.33 \\
I & 10 & 12 & 5 & 41.66 \\
TFP & 3 & 12 & - & - \\
TFP & 5 & 12 & 7 & 58.33 \\
TFP & 10 & 12 & 12 & 100 \\
II & 5 & 12 & 5 & 41.66 \\
II & 10 & 12 & 11 & 91.66 \\
PER & 1 & 12 & -- & - \\
PER & 5 & 12 & 10 & 83.33 \\
PER & 10 & 12 & 12 & 58.33 \\
III & 5 & 12 & 7 & 100 \\
III & 10 & 12 & 12 & \\
\hline
\end{tabular}

3) Influence on the fighting behaviour in paired mice

The technique was similar to that of 'Tedeschi et al. (13) as modified by Dandiya and Menon (14) in all essential details. Pairs of mice were placed on the apparatus and were covered with a bell jar. These were then subjected to a mild intermittent electric shocks. When tested in this way, at least $60 \%$ of the randomly selectcd pairs of mice exhibited two to three fights in one minute. These pairs were then kept in individual cages and were re-examined after one hour of the drug treatment, for the assessment of fighting response. The pairs of mice not fighting even once in one minute were taken as showing no response. All details regarding the drug, doses, and number of pairs tried are mentioned in Table 3.

\section{4) Influence on conditioned avoidance behaviour of trained rats}

The apparatus used and the procedure followed was the same as described by Cook 
and Weidley (15). The unconditioned stimulus consisted of an electric shock of 40 volts through a copper grid floor. Rats were then conditioned so that at the sound of an electric bell, they climb over the ladder kept in a slanting position at the centre of the grid floor of the chamber. During training if the animal failed to respond the sound of the electric bell within 10 seconds, shock was given and the escape response (ER) terminated the shock. Over $90 \%$ of rats learned the required response (CAR) after 4 trials daily for five consecutive days and were judged to be fully conditioned. Intraperitoneally administered doses of the test drugs were given to a group of such trained rats. At hourly intervals, for 3 hours after the drug treatment, these responses (ER or CAR) of each animal were tested. One group of rats receiving only the solvent served as a control. The details are recorded in Table 4.

TABLE 4. Effects of phenothiazine drugs on conditioned avoidance response (GAR) and escape response (ER) of trained rats.

\begin{tabular}{|c|c|c|c|c|c|c|c|c|c|c|c|}
\hline \multirow{2}{*}{ Drug } & \multirow{2}{*}{$\begin{array}{c}\text { Dose } \\
\mathrm{mg} / \mathrm{kg}\end{array}$} & \multirow{2}{*}{$\begin{array}{l}\text { No. of } \\
\text { animals }\end{array}$} & \multicolumn{3}{|c|}{$1 \mathrm{hr}$} & \multicolumn{3}{|c|}{$2 \mathrm{hr}$} & \multirow[b]{2}{*}{$\begin{array}{l}\text { Loss } \\
\text { CAR }\end{array}$} & \multicolumn{2}{|l|}{$3 \mathrm{hr}$} \\
\hline & & & $\begin{array}{l}\text { Loss } \\
\text { CAR }\end{array}$ & $\begin{array}{l}\text { Loss } \\
\text { ER }\end{array}$ & $\begin{array}{l}\% \text { loss } \\
\text { CAR }\end{array}$ & $\begin{array}{l}\text { Loss } \\
\text { CAR }\end{array}$ & $\begin{array}{c}\text { Loss } \\
\text { ER }\end{array}$ & $\begin{array}{c}\% \text { loss } \\
\text { CAR }\end{array}$ & & $\begin{array}{c}\text { Loss } \\
\text { ER }\end{array}$ & $\begin{array}{c}\% \text { loss } \\
\text { CAR }\end{array}$ \\
\hline Gontrol & - & 12 & - & - & - & - & - & - & - & - & - \\
\hline GPZ & 7 & 12 & 10 & 6 & 83.33 & 11 & 6 & 91.66 & 11 & 6 & 91.66 \\
\hline GPZ & 3 & 12 & 6 & - & 50 & 6 & - & 50 & 6 & - & 50 \\
\hline I & 10 & 12 & 5 & $\ldots$ & 41.66 & 7 & - & 58.33 & 6 & - & 50 \\
\hline I & 7 & 12 & 2 & - & 16.66 & 3 & - & 25 & 3 & - & 25 \\
\hline $\mathrm{I}$ & 3 & 12 & 0 & 一 & - & - & - & - & - & - & - \\
\hline TFP & 3 & 10 & 8 & 6 & 80 & 10 & 8 & 100 & 10 & 8 & 100 \\
\hline TFP & 1 & 10 & 4 & 1 & 40 & 8 & 2 & 80 & 9 & - & 90 \\
\hline II & 3 & 12 & 6 & - & 50 & 8 & - & 66.6 & 10 & 2 & 83.3 \\
\hline II & 1 & 8 & 1 & - & 12.5 & 2 & - & 25 & 2 & 一 & 25 \\
\hline PER & 3 & 10 & 10 & 10 & 100 & 10 & 10 & 100 & 10 & 10 & 100 \\
\hline PER & 1 & 10 & 4 & - & 40 & 8 & 2 & 80 & 8 & 3 & 80 \\
\hline III & 3 & 12 & 4 & $\rightarrow$ & 33.3 & 11 & 4 & 91.66 & 11 & 4 & 91.66 \\
\hline III & 1 & 12 & - & - & - & 5 & - & 41.66 & 5 & $\rightarrow$ & 41.66 \\
\hline
\end{tabular}

TABLE 5. Effects of phenothiazines on the amphetamine toxicity in aggregated mice.

\begin{tabular}{|c|c|c|c|c|c|c|c|c|c|}
\hline \multirow{2}{*}{ Drug } & \multirow{2}{*}{$\begin{array}{c}\text { Dose } \\
\mathrm{mg} / \mathrm{kg}\end{array}$} & \multirow{2}{*}{$\begin{array}{l}\text { No. of } \\
\text { animals }\end{array}$} & \multicolumn{6}{|c|}{ No. of the animals died after } & \multirow{2}{*}{$\begin{array}{l}\% \text { death } \\
\text { after } 18 \mathrm{hr}\end{array}$} \\
\hline & & & $1 \mathrm{hr}$ & $2 \mathrm{hr}$ & $3 \mathrm{hr}$ & $4 \mathrm{hr}$ & $6 \mathrm{hr}$ & $18 \mathrm{hr}$ & \\
\hline GPZ & 3 & 10 & - & 1 & - & - & - & 1 & 20 \\
\hline I & 10 & 10 & 2 & - & - & - & - & 1 & 30 \\
\hline I & 3 & 10 & 4 & 1 & 1 & - & 2 & -- & 80 \\
\hline TFP & 3 & 10 & - & - & - & - & - & - & 0 \\
\hline TFP & 1 & 10 & - & 1 & 1 & - & - & $\rightarrow$ & 20 \\
\hline II & 3 & 10 & 2 & - & - & - & - & - & 20 \\
\hline II & 1 & 10 & 2 & 2 & 1 & - & 2 & - & 70 \\
\hline PER & 3 & 10 & - & - & - & - & - & - & 0 \\
\hline PER & 1 & 10 & - & 1 & 1 & 1 & - & - & 30 \\
\hline III & 3 & 10 & - & - & - & - & - & . & 0 \\
\hline III & 1 & 10 & - & I & 1 & - & 1 & - & 30 \\
\hline
\end{tabular}


5) Protective effects to the amphetamine toxicity in aggregated mice

Albino mice of either sex were divided into twelve grougs of 10 animals each, distributing males and females equally in each group. These were kept aggregated in metallic cages $(25 \mathrm{~cm} \times 13 \mathrm{~cm} \times 12 \mathrm{~cm})$ having wire meshed walls. In one group of mice, solvent was administered and followed one hour later by $d$-amphetamine sulphate in a dose of $70 \mathrm{mg} / \mathrm{kg}$ given intraperitoneally as suggested by Morpurgo (16). The other groups were pretreated with subcutaneous injections of different doses of test compounds and received the same dose $(70 \mathrm{mg} / \mathrm{kg}$ ) of $d$-amphetamine (i. p.) after one hour. These groups were then observed at hourly intervals till first four hours, then at 6th and lastly at 18 th hour. The dead animals were removed at the time of each observation. At the end of the experiment, the number of the surviving animals in each group were noted. The results are shown in Table 5.

TABLE 6. Solubilities at $\mathrm{pH} 7.4$ of the phenothiazine derivatives under study.

\begin{tabular}{ccccc}
\hline S. No. & Drug & $\lambda$ Max m $\mu$ & $\begin{array}{c}\text { Solubility in } \\
\text { parts/million }\end{array}$ & \multicolumn{2}{c}{$\begin{array}{c}\text { Calculated relative } \\
\text { solubility at pH } 7.4\end{array}$} \\
\cline { 2 - 5 } 1. & CPZ & 255 & 100 & 1 \\
2. & TFP & 258 & 40 & $0.4^{*}$ \\
3. & PER & 255 & 38 & $0.38^{*}$ \\
4. & I & 255 & 458 & 4.58 \\
5. & II & 258 & 83 & 0.83 \\
6. & III & 255 & 60 & 0.60 \\
\hline
\end{tabular}

$*_{\text {lit }}^{18}$ reports. 0.3 and 0.35 for $T F P$ and PER respectively.

6) *Relative solubilities at $p H 7.4$

The method followed was the same as described earlier by Sharma et al. (17). The solubilities of the drugs expressed in parts per million are listed in the third column of the Table 6 while the calculated solubility of each drug at $\mathrm{pH} 7.4$, relative to that of CPZ are given in the final column of the same Table. Since the optical densities of the saturated solutions of each compound, at the wave length of the maximum absorption, were generally not within the scale of the spectrophotometer, these were diluted as follows :

$\begin{array}{ccl}\text { Gompound } & \text { Dilution } & \text { Solution used } \\ \text { CPZ } & 100 & \text { Saturated } / 100 \\ \text { TFP } & 50 & \text { Saturated } / 50 \\ \text { PER } & 25 & \text { Saturated } / 25 \\ \text { I } & 100 & \text { Saturated } / 100 \\ \text { II } & 50 & \text { Saturated } / 50 \\ \text { III } & 25 & \text { Saturated } / 25\end{array}$

The optical density thus obtained for each solution of unknown concentration was then converted into the concentration of the dissolved compound, using a calibration graph obtained by plotting optical densities against the known concentrations of the compound

* Such a study was undertaken because Green (18) has recently shown that the potent tranquillizing drugs of phenothiazinc scrics, all have relative solubilities of one or less, with CPZ as standard. These findings are, therefore, expected to support the pharmacological data qualitatively, if not quantitatively. 

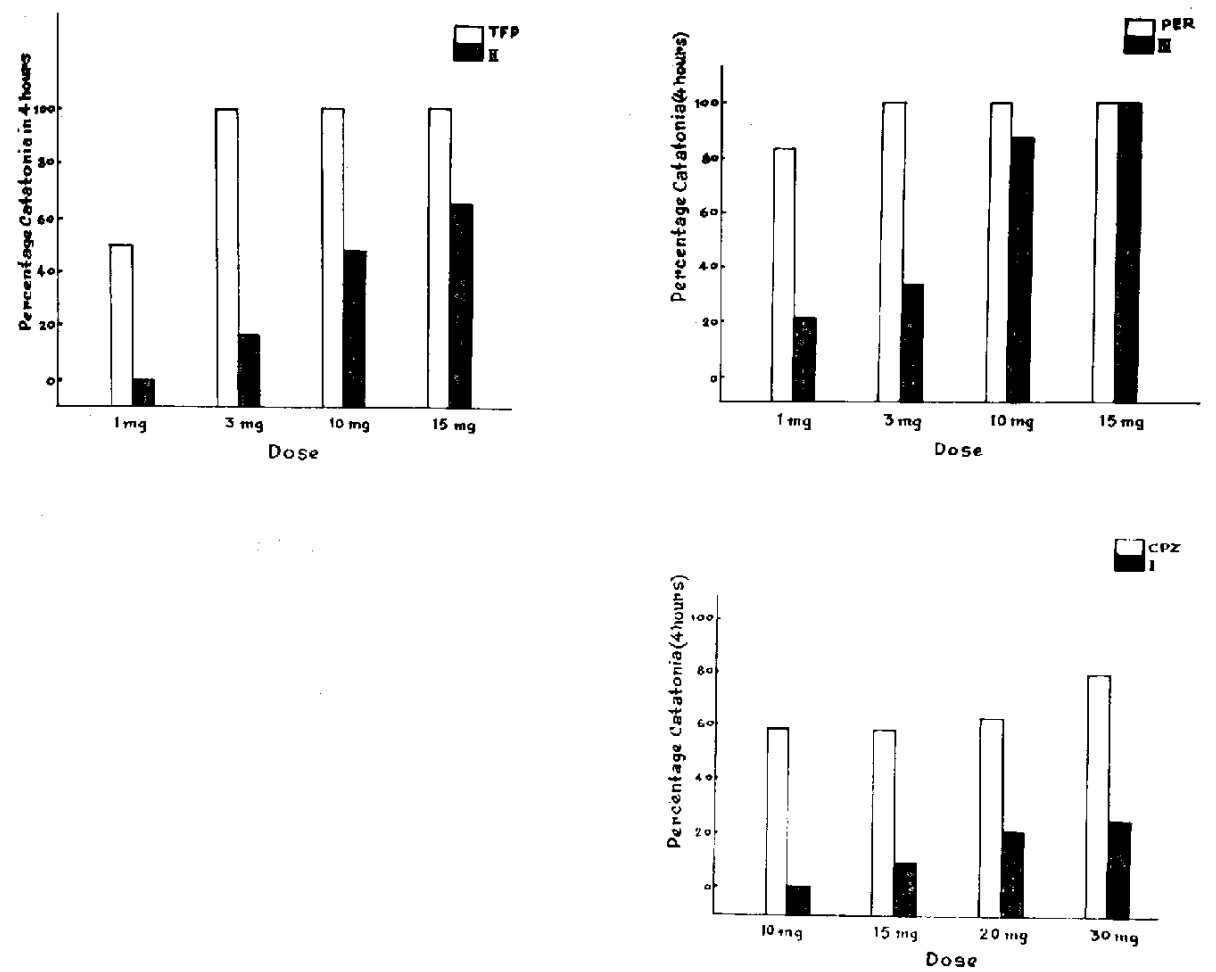

Fig. 2. A comparative intensity of the cataleptic response (\%) at 4 th hour.

in phosphate buff.r ( $\mathrm{pH}$ 7.4). The value of the concentration thus obtained (ppm) was multiplied by the required dilution factor to get the solubilities in parts per million (ppm). 'l'ypical plots are shown in Fig. 2.

III. Scoring of the intensity of the cataleptic reaction in rats*

The study of drug induced catalepsy on white albino rats of average weight of 200 $250 \mathrm{~g}$ was made, by evaluating their failure to corrcct the imposed postures of the body. The intensity of the response was scored for each animal according to the stages III and IV as described by Wirth et al. (19) and Morpurgo (16). In stage III the rats were

* Though it is difficult to producc parkinsonism in laboratory animals, few mcans are, however, available to produce symptoms similar to those of parkinsonism (20). A characteristic property of a neuroleptic drug is the ability to inducc catatonic like state in experimental animals, which may be regarded as the counterpart of extrapyramidal reaction in human beings (16). Thereforc, some workers have used a method of "drug induced catalepsy on rats" for an assessment of parkinsonism liability of a drug. In the present study, this method was, however, followcd because of the following reason.

Barbcau (21) has proposcd the following modification to McGeer's hypotheses: (i) an imbalance in a system linking dopamine-acetylcholine, would result in symptoms like rigidity and akincsia (ii) a disequilibrium betwcen serotonin-histamine system would produce tremors and akathisia. Since our aim was to correct the extrapyramidal dysfunction by decreasing the neurohumoral content of acetylcholine (of dopamine-acetylcholine system), the method of choice to assess and comparc the parkinsonism liability should have bcen to study the drug induced catatonia in rats. It is pertinent here to mention that the percent incidence and frequency of tremors and akathisia caused by phenothiazines has been reported (22) to be less as compared to akinesia and rigidity. This further strengthened our view to increase the antiacctylcholine like activity of phenothiazine tranquillizers. 
placed with one of the front paws set on a cork of $3 \mathrm{~cm}$ height, while the other paw remaincd on the table. In stage IV, one of the front paws was set on a cork of $9 \mathrm{~cm}$ height, the other hanging free. The failure to correct the imposed posture within 10 seconds was considered as the positive catatonic reaction. Both the stages (III and IV) were tested on the right and the left sides. Half $(1 / 2)$ point for each side of stage III, and one (I) point for each side of stage IV were arbitrarily assigned for each positive response. The catatonic reactions were evaluated at hourly intervals, after the administration of phenothiazine derivatives, till the fourth hour. The percent catatonic response was employed as a criterion to assess parkinsonism liability of the phenothiazine derivatives under study. The results are listed in Table 7. A graphic representation of the comparative intensity of the cateleptic response at 4th hour, induced by three test compounds (I, II III and their parent drugs (CPZ, TFP and PER) are shown in Fig. 3.

TABLE 7. Effects of phenothiazine drugs on the cataleptic reaction in rats.

Max. points : 24

\begin{tabular}{|c|c|c|c|c|c|c|c|c|c|c|}
\hline \multirow{3}{*}{ Drug } & \multirow{3}{*}{$\begin{array}{c}\text { Dose } \\
\mathrm{mg} / \mathrm{kg}\end{array}$} & \multirow{3}{*}{$\begin{array}{l}\text { No. of } \\
\text { animals }\end{array}$} & \multicolumn{8}{|c|}{ Score of catatonic response } \\
\hline & & & \multicolumn{2}{|c|}{$1 \mathrm{hr}$} & \multicolumn{2}{|c|}{$2 \mathrm{hr}$} & \multicolumn{2}{|c|}{$3 \mathrm{hr}$} & \multicolumn{2}{|c|}{$4 \mathrm{hr}$} \\
\hline & & & Points & $\%$ & Points & $\%$ & Points & $\%$ & Points & $\%$ \\
\hline GPZ & 10 & 8 & 12 & 50 & 14 & 58.3 & 15 & 62.5 & 14 & 58.3 \\
\hline $\mathrm{CPZ}$ & 15 & 8 & 13 & 54.2 & 15 & 62.5 & 15 & 62.5 & 14 & 58.3 \\
\hline $\mathrm{CPZ}$ & 20 & 8 & 14 & 58.3 & 15 & 62.5 & 14 & 58.3 & 15 & 62.5 \\
\hline $\mathrm{CPZ}$ & 30 & 8 & 16 & 66.6 & 20 & 83.3 & 20 & 83.3 & 19 & 79.1 \\
\hline I & 10 & 8 & 0 & 0 & 0 & 0 & 0 & 0 & 0 & 0 \\
\hline I & 15 & 8 & 1 & 4.1 & 2 & 8.3 & 2 & 8.3 & 2 & 8.3 \\
\hline I & 20 & 8 & 4 & 16.6 & 4 & 16.6 & 5 & 20.8 & 5 & 20.8 \\
\hline I & 30 & 8 & 6 & 25 & 6 & 25 & 5 & 20.8 & 6 & 25 \\
\hline TFP & 1 & 8 & 1 & 4.16 & 9 & 37.50 & 11 & 45.83 & 12 & 50 \\
\hline TFP & 3 & 8 & 13 & 54.16 & 21 & 87.50 & 24 & 100 & 24 & 100 \\
\hline $\mathrm{TFP}$ & 10 & 8 & 12 & 50 & 22 & 91.66 & 24 & 100 & 24 & 100 \\
\hline TFP & 15 & 8 & 12 & 50 & 24 & 100 & 24 & 100 & 24 & 100 \\
\hline II & l & 8 & 0 & 0 & 0 & 0 & 0 & 0 & 0 & 0 \\
\hline II & 3 & 8 & 0 & 0 & $1 \frac{1}{2}$ & 6.25 & 5 & 20.83 & 4 & 16.66 \\
\hline II & 10 & 8 & $2 \frac{1}{2}$ & 10.41 & $12 \frac{1}{2}$ & 52.08 & 11 & 45.83 & $11 \frac{1}{2}$ & 47.91 \\
\hline II & 13 & 8 & 3 & 12.50 & $11 \frac{1}{2}$ & 47.91 & 15 & 62.50 & $15 \frac{1}{2}$ & 64.58 \\
\hline PER & 1 & 8 & 17 & 70.83 & 15 & 62.50 & 20 & 83.33 & 20 & 83.33 \\
\hline PER & 3 & 8 & 20 & 83.33 & 24 & 100 & 24 & 100 & 24 & 100 \\
\hline PER & 10 & 8 & 24 & 100 & 24 & 100 & 24 & 100 & 24 & 100 \\
\hline PER & 15 & 8 & 24 & 100 & 24 & 100 & 24 & 100 & 24 & 100 \\
\hline III & 1 & 8 & $\frac{1}{2}$ & 2.08 & $3 \frac{1}{2}$ & 12.81 & 5 & 20.83 & 5 & 20.83 \\
\hline III & 3 & 8 & $6 \frac{1}{2}$ & 27.08 & 6 & 25 & 8 & 33.33 & 8 & 33.33 \\
\hline III & 10 & 8 & 11 & 45.83 & 17 & 70.83 & 21 & 87.50 & 21 & 87.50 \\
\hline III & 15 & 8 & 14 & 58.33 & 23 & 95.83 & 24 & 100 & 24 & 100 \\
\hline
\end{tabular}



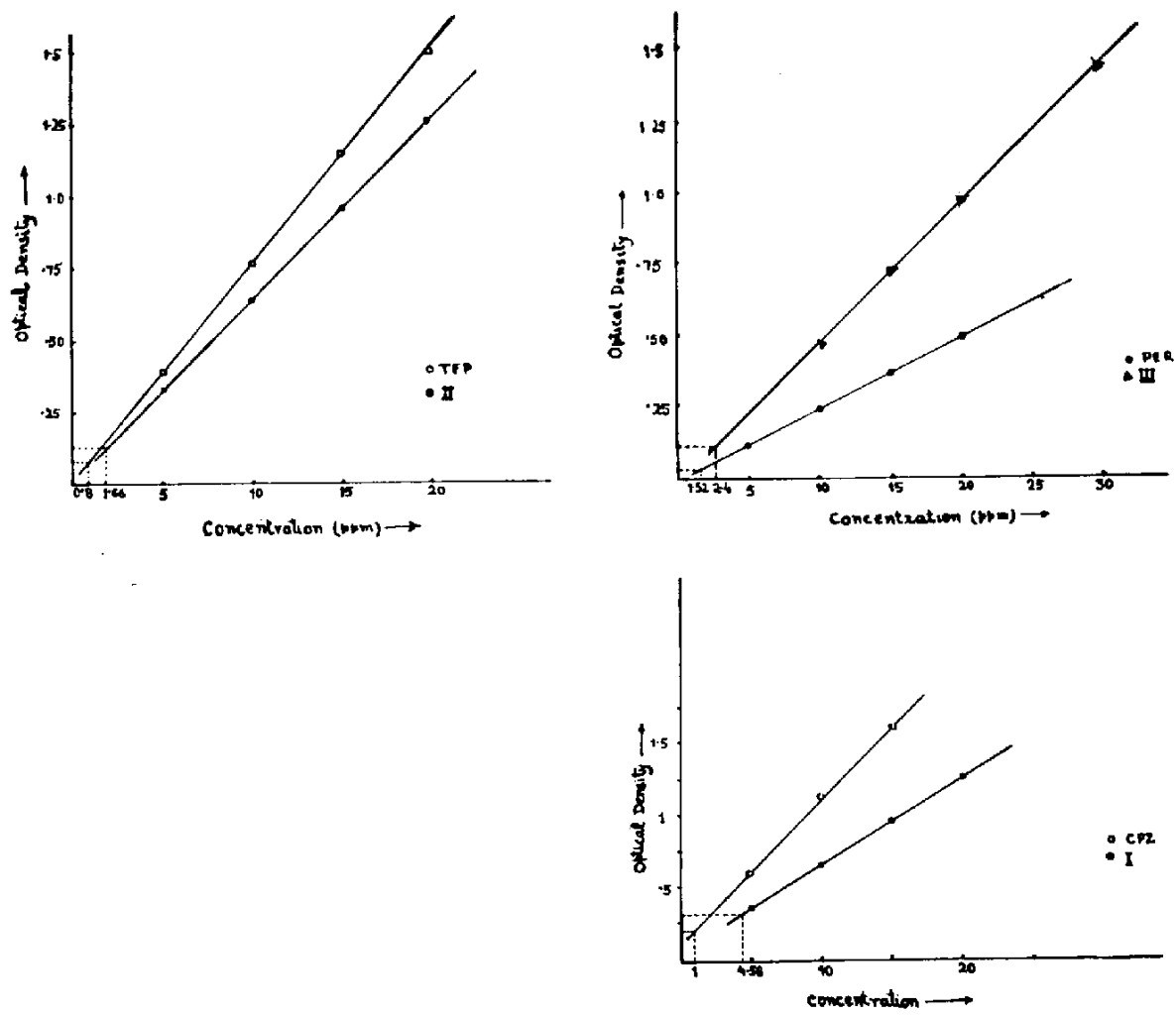

FIG. 3. Plot of optical densities against the concentration of phenothiazines (CPZ, TFP, PER, I, II and III), showing their relative solubilities at $\mathrm{pH} 7.4$.

\section{RESULTS AND DISCUSSION}

A contemplation of Fig. 3 and of the results cited in Table 7 would indicate that the catatonic liability of the compounds I, II and III is considerably less as compared to their parent drugs viz. CPZ, TFP and PER. The compound I exhibited only insignificant catatonia $(24 \%)$ till $30 \mathrm{mg} / \mathrm{kg}$ dose while GPZ even at a dose level of $10 \mathrm{mg} / \mathrm{kg}$ produced $57.3 \%$ catatonic reaction. The compound II produced only about $65 \%$ catatonia at a dose level as high as $15 \mathrm{mg} / \mathrm{kg}$ which compared well with only $1 \mathrm{mg} / \mathrm{kg}$ dose of the parent drug TFP. upto $3 \mathrm{mg} / \mathrm{kg}$, II practically did not produce any significant imbalance of posture (20\% catatonia) while TFP, on the other hand, exhibited $100 \%$ catatonia at the same dose level. Similarly, compound III induced only $87 \%$ catatonia in rats at a dose as high as $10 \mathrm{mg} / \mathrm{kg}$ but PER itself produced equivalent catatonic reaction at a little over $1 \mathrm{mg} / \mathrm{kg}$ dose level.

Since these derivatives (I, II and III) offered a marked reduction in the liability of parkinsonism over their parent drugs (CPZ, TFP and PER) it is of interest to draw a conclusion as to what extent do these derivatives arc devoid of tranquillizing activity.

In general thcse derivatives affected SMA to a lesser extent as compared to their parent drugs (cf. Table 1). The compound I did not affect SMA, ptosis as well as the response of tactile and auditory stimuli at $3 \mathrm{mg} / \mathrm{kg}$ dose level. Ptosis and significant loss 
of SMA could only be observed at a dose of $10 \mathrm{mg} / \mathrm{kg}$ while response to tactile stimuli was still normal. With compound II, though SMA was lowered at a little higher doses (e.g. $3 \mathrm{mg} / \mathrm{kg}$ of II compared well with $1 \mathrm{mg} / \mathrm{kg}$ dose of TFP), the response to tactile stimuli was still not lost. Similar was the case with compound III and PER.

A comparison of the potencies of all the six phenothiazines to potentiate pentobarbitone sodium induced hypnosis, indicatcd that it was not much altered in case of II and I'TP or III and PER, but $I$ has a markedly decreased ability to induce slcep as compared to its parent drug CPZ (cf. Table 2).

According to Tedeschi et al. (13) "the fighting behaviour in paired mice" is a uscful test for the evaluation of centrally acting muscle relaxanis like meprobamatc. Turner (23) has however, suggested that this test is a more sensitive index for evaluation of the tranquillizing property. These views drew our interest in this technique. It was found that at a dose as low as $1 \mathrm{mg} / \mathrm{kg}$ of TFP which could significantly block $\mathrm{C} \Lambda \mathrm{R}$ in rats failed to abolish fighting behaviour in paired mice till $5 \mathrm{mg} / \mathrm{kg}$ dose was cmployed $(58.3 \%$ block). GPZ was found to be more effective than TFP in blocking the fighting response, because $3 \mathrm{mg} / \mathrm{kg}$ dose of $\mathrm{CPZ}$ could block $25 \%$ fighting response which was blocked by the equivalent dose of TFP at all. As C.PZ is a weaker tranquillizer and a stronger sedative than TFP (24), it provides an additional evidence that this method is not an appropriate method for evaluating tranquillizers of phenothiazine series at least. Our findings are consistcnt with Tedeschi et al. (13) and thus the tranquillizers like phenothiazines can abolish this response only in doses which cause motor incapacitation and as such this technique is unsuitable for testing tranquillizing property.

As is evident from Table 4 a delayed onset of activity was observed with I, II and III as compared to their parent drugs viz. CPZ, TFP and PER. The compound I at a dose lcvel of $10 \mathrm{mg} / \mathrm{kg}(50 \%$ block of CAR) compared well with $3 \mathrm{mg} / \mathrm{kg}$ dose of CPZ ( $50 \%$ block of CAR); thus indicating that it was about three times less potent than CPZ. Trifluoperazine (TFP) at $1 \mathrm{mg} / \mathrm{kg}$ dose exhibited $90 \%$ block of CAR while $83.3 \%$ block of CAR was obtained at a dose of $3 \mathrm{mg} / \mathrm{kg}$ of compound II ; showing that the latter was approximately one third as potent as TFP. Both compounds III and PER at $3 \mathrm{mg} / \mathrm{kg}$ dose did not exhibit any marked difference in the activity, though the former was definitely less potent than the latter. Interestingly, all the three derivatives (I, II and III) blocked the escape response (ER) to a considerably lesser extent as comparcd to their parent drugs (CPZ, TFP and PER). Though less potent than their parent drugs, these compounds can prove to be better drugs owing to their negligible incapacitation of motor function.

The effects of these six phenothiazine derivatives were studied on amphetamine toxicity in aggregated mice (cf. Tablc 5). It was observed that PER and III were equipotent in providing protection to the toxicity. II at a dose of $3 \mathrm{mg} / \mathrm{kg}$ offered $20 \%$ protection which could be obtained by giving $1 \mathrm{mg} / \mathrm{kg}$ dose of TFP; showing thereby that it was one third as potent as TFP. The compound III was found to be roughly about 3 timcs less potent than $\mathrm{CPZ}$ as its $10 \mathrm{mg} / \mathrm{kg}$ dose offered $30 \%$ protection which 
was obtained by $3 \mathrm{mg} / \mathrm{kg}$ dose of CPZ.

A perusal of 'lable 6 would indicate that there is no significant difference between the values of solubilities, of TFP and PER relative to that of CPZ as standard, obtaincd by our method (17) and those quoted by Grecn (18). According to Green the values of relative solubilities are $1.0 ; 0.30$; and 0.35 for CPZ, TFP and PER while, our values are $1.00,0.40$ and 0.38 respectively. This minor difference between the values might have been duc to several reasons e.g. Green (18) has determined the solubilities at temperature $\left(24 \pm 1^{\circ} \mathrm{C}\right.$ ) using the buffer ( $\left.\mathrm{pH} 7.4\right)$ as suggested by Gomori (25); while in the present study the solubilities were determined at $\left(31 \pm 1^{\circ} \mathrm{C}\right)$ using the phosphate buffer $(\mathrm{pH} 7.4)$ (26). Moreover some workers have reported that the aminoalkylphenothiazines have a high surface activity and a tendency to form miscelles $(27,28)$. Thus some supersaturation might have occurred during the precipitation of the free base from the solution during the preparation of the saturated solution of the drug in the buffer. As a consequence, the values of truc solubilities would apparently be lower than those obtained by our procedure. The values of relative solubilities of all the test compounds are given in the final column of Table 6 . It is evident that III have the relative solubilities of 0.83 and 0.60 respectively i.e. they fall in a group of potent tranquillizers while I with a relative solubility of 4.58 appears to be a weck tranquillizer. These findings are consistent with Green's (18) observations and support the pharmacological data at least qualitatively.

From the results discussed above it is apparent that the tranquillizing property of II is one third to that of TFP but $3 \mathrm{mg} / \mathrm{kg}$ dose of the former (II) produced $20 \%$ catatonia, while only $1 \mathrm{mg} / \mathrm{kg}$ dose of the latter (TFP) exhibited $65 \%$ catatonia; equivalent dose $(3 \mathrm{mg} / \mathrm{kg}$ of TFP exhibited $100 \%$ catatonia. Similarly, although, lesser potency was exhibitcd by III than PER, the latter cven at a dose of $1 \mathrm{mg} / \mathrm{kg}$ induced catatonic reactoin equivalent to $10 \mathrm{mg} / \mathrm{kg}$ dose of the former (PER). In case of $\mathrm{I}$, though the catalepsy liability was almost negligible, it also lost the tranquillizing ability to a greater extent compared to GPZ. It could bring about tranquillization only when a dose of as 10 $\mathrm{mg} / \mathrm{kg}$ was employed.

Therefore it could be speculated that the tranquillization potcncy it also decreased along with the decrease of parkinsonism liability. But this decrease is not proportional because, both II and III although exhibited little decrease in tranquillizing activity, there was a marked reduction in the catatonic liability as compared to TFP and PER respectively. Thus it seems that it is possible to decrease parkinsonism liability grcatly, with a little loss of tranquillizing activity and probably a positive correlation between the extrapyramidal reactions and the antipsychotic activity docs not exist. Perhaps, minor disturbance of the extrapyramidal tract are, however, always associated with tranquillization. Finally these studies indicate that diphenacyloxime trifluoperazine dibromide (II) and diphenacyloximc perphenazine dibromide (III) may prove to be promising therapeutic agents. 


\section{SUMMARY}

Since phenothiazines are the valuable drugs in psychiatry, control of their extrapyramidal side effects offers an important challenge. A review of literature, regarding the biochemical alterations produced by drug induced parkinsonism, clearly indicates that the only way to reduce parkinsonism liability of these drugs is to increase their antiacetylcholine like activity. Since oximes are generally used as antidotes in case of organophosphorous poisoning, one can speculate that anticholinergic compounds of these kinds can provide a tranquillizer with lesser liability for Parkinson disease. Thus some quaternary oximes of phenothiazinc drugs were synthesized. These compound were assessed for their parkinsonism liability. Their CNS depressant properties were also studied and compared with their parent drugs. From these studies, it appeared that it is possible to decrease the parkinsonism liability to a greater extent, with only a little loss of antipsychotic activity and probably a positive correlation between these two biological actions, one desirable and the other unwanted, does not exist.

Acknowledgements: We thank Council of Scientific and Industrial Research, India for a maintenance grant during the course of this work.

\section{REFERENCES}

1) Holerster, L.E.: Clin. Pharmac. Ther. 5, 321 (1964)

2) Freyhan, F.A.: The Relationship of Drug Induced Neurological Phenomena on Therapeutic Outcome, Edited by Brodeteau, J.M., Extrapyramidal System and Neuroleptics, p. 483, Montreal (1961)

3) Brune, G.G., Monpurco, G., Brelkus, A., Kobayasin, T., Tourlentes, T.T. nnd Himwicit, H.E.: Comprehens. Psychiat. 3, 227 (1962)

4) HAAsr, H.J.: Extrapyramidal Modification of Fine Movements, a "Conditio sine qua non" of the Fundamental Therapeutic Action of Neuroleptic Drugs, Edited by Bropeleau, J.M., Fxtrapyramidal System and' Neuroleptics, p. 329, Montreal (1961)

5) Cole, J.O. And Glyde, D.J.: Rev. Can. Biol. 20, 565 (1961)

6) Brooks, G.W.: Nere Engl. J. Med. 254, 1119 (1956)

7) McGeer, P.L., Boulding, J.E., Gibson, W.G. nnd Four.kes, R.G.: J. Am. Med. Assoc. 177, 665 (1961)

8) Tedeschi, D.H., Tedeschi, R.E. And Fellows, E.J.: Archs int. Pharmacodyn. Thér. 132, 172 (1961)

9) Webster, R.A.: Br. J. Pharmac. Chemother. 25, 566 (1965)

10) Silarma, H.L., Banerjee, S.P., Silarma, V.N. and Mital, R.L.: J. Med. Chem. (in press, Nov. issue)

11) Dandrya, P.G. And Menon, M.K.: J. Pharmac. exp. Ther. 145, 42 (1964)

12) Dandiya, P.C. and Cullumbine, H. J. Pharmac, exp. Thier. 125, 353 (1959)

13) Tenfscin, R.E., Tedesciit, D.H., Mucha, A., Cook, L., Matris, P.A. And Tellows, E. J.: J. Pharmac. exp. Ther. 125, 28 (1959)

14) Dandiya, P.C. And Menon, M.K.: Br. J. Pharmac. Chemother. 20, 436 (1963)

15) Cook, L. AND Wriduey, E.: Ann. N.Y. Acad. Sci. 66, 740 (1957)

16) Monpukgo, C.: Antiparkinson Drugs and Neuroleptics, Edited by Himwich, W.A. And Scimade, P.P., Progress in Brain Research, Vol. 16, p. 121, Elseveir, Amsterdam (1965)

17) Sharma, H.L., Banerjee, S.P., Sharma, V.N. ano Mrtal, R.L.: J. Pharma. Pharmac. (Contributed)

18) GreEN, A.L.: J. Pharm. Pharmac. 19, 10 (1967) 
19) Wirti, W., Gosswald, R., Horlein, U., Risse, K.L.H. and Kreiskott, H.: Archs int. Pharmacodyn. Thér. 115, 1 (1958)

20) Everett, G.M.: Animal and Clinical Techniques for Evaluating Antiparkinson Agents, Edited by NoDrNe, J.H. AND SIegler, P.E., Pharmacologic Techniques in Drug Evaluation, p. 359, Year Book Medical Publishers Inc., Chicago (1964)

21) Barbeau, A.: Can. med. Ass. J. 87, 802 (1962)

22) Haase, H.J. and Janssen, P.A.J.: The Action of Neuroleplic Drugs, p. 83, North Holland Publishing Co., Amsterdam (1965)

23) Turner, R.A.: Screening Method in Pharmacology, p. 96, Academic Press, London (1965)

24) Dimascio, A., Havens, L.L. and Klerman, G.L.: J. Nerv. Ment. Dis. 136, 15; 168 (1963)

25) Gomori, G.: Preparation of Buffers for Use in Enzyme Studies, Edited by Colowick, S.P. AND KaPLAN, N.O., Methods in Enzymology, Vol. 1, p. 138, Academic Press, Ncw York (1955)

26) The United State Pharmacopeia (USP), New York, XVII revision, p. 913 (1965)

27) SCholtan, W.: Kolloidzeitschrift 142, 84 (1955)

28) Sfeman, P.M. And Bialy, H.S.: Biochem. Pharmac. 12, 1181 (1963) 